British Art Studies

Issue 15, published 27 February 2020

Cover image: Laura Grace Ford, Alpha, Isis, Eden, installation photograph, 1

February - 18 March 2017, multi-media installation made in collaboration with sound engineer Jack Latham.. Digital image courtesy of Laura Grace Ford.

PDF generated on 14 April 2022

Note: British Art Studies is a digital publication and intended to be experienced online and referenced digitally. PDFs are provided for ease of reading offline. Please do not reference the PDF in academic citations: we recommend the use of DOIs (digital object identifiers) provided within the online article. These unique alphanumeric strings identify content and provide a persistent link to a location on the internet. A DOI is guaranteed never to change, so you can use it to link permanently to electronic documents with confidence.

Published by:

Paul Mellon Centre

16 Bedford Square London, WC1B 3JA

https://www.paul-mellon-centre.ac.uk

In partnership with:

Yale Center for British Art 1080 Chapel Street

New Haven, Connecticut

https://britishart.yale.edu

ISSN: 2058-5462

DOI: 10.17658/issn.2058-5462

URL: https://www.britishartstudies.ac.uk

Editorial team: https://www.britishartstudies.ac.uk/about/editorial-team Advisory board: https://www.britishartstudies.ac.uk/about/advisory-board

Produced in the United Kingdom.

\section{Ajoint publication by}




\section{Contents}

Skin and Bone: Surface and Substance in Anglo-Colonial Portraiture, David Hansen 


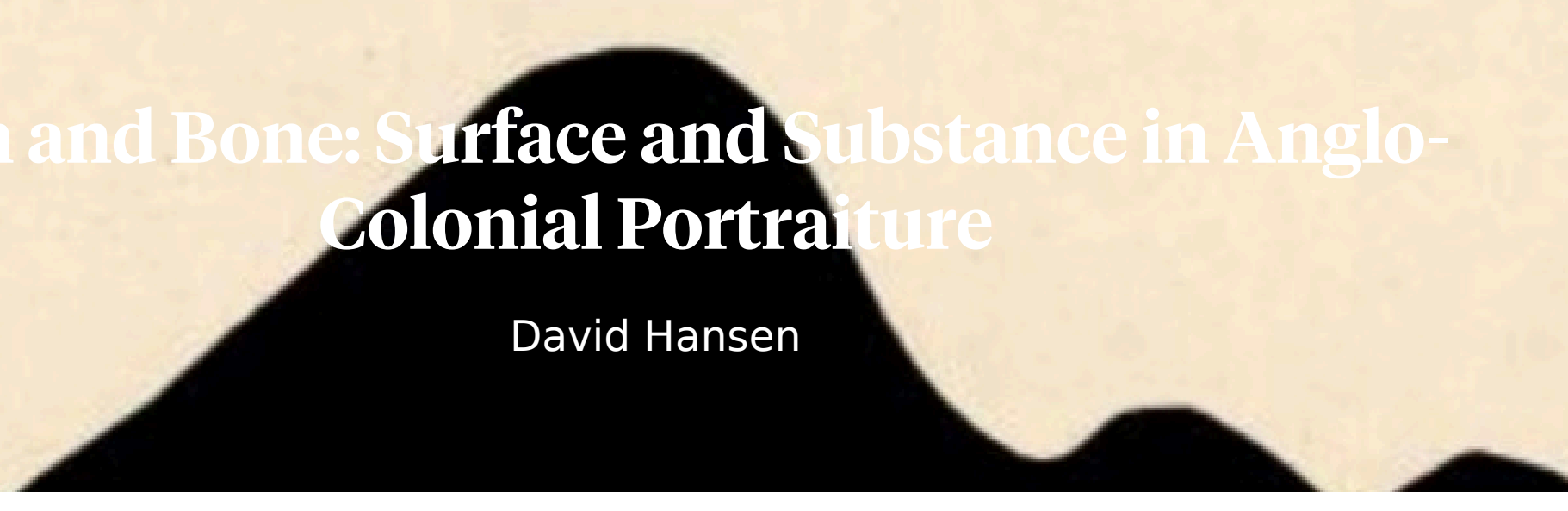

\section{Abstract}

This visual essay takes an exploratory tour through certain aspects of portraiture in Britain, continental Europe, America, and Australia, from the late eighteenth to the mid-nineteenth centuries. Investigating the physiognomies of politics and sensibility, class and race, across numerous specific historical circumstances and occurrences, it is very much driven by and dependent upon its pictorial content; on the flicker of images in the mind's eye of the author and in that of the viewer-auditor-reader. This essay considers the relationship between the coastal profile, the silhouette, and the phrenology head; between the theodolite, the pointing machine, and the craniometer; between the contour map, the cameo, and the death mask. It also ventures into the topology of portraiture, the geometries through which portraits and maps are presented: both quadrilateral frames and grids, and oval or circular medallions. By presenting materials which are functionally and materially diverse but clearly related in appearance, and time and place of origin, this essay suggests that the public and popular cultures of the British imperium spread a wider and weirder net than is conventionally supposed.

\section{Authors}

Associate Professor, Centre for Art History and Art Theory, Australian National University.

\section{Acknowledgements}

In offering Skin and Bone as a time-based digital product, I hope to convey something of the phenomenology of art history, or at least of my art history. I am immensely grateful to Sarah Turner and the British Art Studies team for their willingness to embrace this somewhat unconventional methodology. The first (and only previous) manifestation of this essay was as a keynote address to the 2016 conference Human Kind: Transforming Identity in British and Australian portraits 1700-1914, organised jointly by the University of Melbourne and the National Gallery of Victoria, with support from the Paul Mellon Centre and the Australian Institute of Art History. My sincere thanks to 
Deidre Coleman, Vivien Gaston, and Alison Inglis for inviting me to give that lecture. Thanks also to Kate Fullagar, Macquarie University and the Australian Research Council-funded Facing New Worlds project, through which I have recently obtained the necessary time to prepare this material for publication.

\section{Cite as}

David Hansen, "Skin and Bone: Surface and Substance in Anglo-Colonial Portraiture", British Art Studies, Issue 15, https://dx.doi.org/10.17658/ issn.2058-5462/issue-15/dhansen 


\title{
Visual Essay and Transcript
}

\author{
View this illustration online
}

\section{Figure 1.}

David Hansen, Skin and Bone: Surface and Substance in Anglo-Colonial Portraiture, 52 minutes 51 seconds, 2020.

Let us start at the beginning, with The Origin of Painting. Well, if not at the very beginning, at least with my beginning. Just six months before I was born, Robert Rosenblum, that marvellous, contrarian art historian who gave us the notion of the Abstract Sublime, and who first situated the beginnings of modern art in eighteenth-century neo-classicism, published in the Art Bulletin "The Origin of Painting: a Problem in the Iconography of Romantic Classicism". $\underline{1}$

In this vintage (though I hasten to add far from geriatric) essay, Rosenblum examines the various transformations from the late seventeenth to the midnineteenth centuries of the imagery of the Corinthian Maid, the famous origin myth related by Pliny the Elder. In Book XXXV of the Naturalis Historia, the beginnings of art are (quite literally) traced to a young Greek woman, Dibutades, who, knowing that her lover was about to go on a long journey, made a memorial drawing of his facial profile from the shadow cast by a lamp against the wall. Rosenblum notes the clear coincidence of the story's Graeco-Roman setting with the neo-classical taste of late eighteenth-century Europe, not only in terms of literary pretension but also in what he describes as the period's "stylistic tendency ... towards increasingly clean-cut, continuous contours and a flattening of forms against the picture plane." 2

Originating in Early Modern connoisseurship and collecting of antique gems and pottery, accelerated by the excavations of Herculaneum and Pompeii, circulated through luxury illustrated publications and advocated in the writings of Johann Winckelmann and others, this taste for the 'noble outline' was enthusiastically embraced both by British Grand Tour milordi and by their cultural courtiers: from Robert Adam to William Chambers, from Gavin Hamilton to John Flaxman, from James Tassie to Josiah Wedgwood.

This is where I really wish to begin, then: with the margin, the boundary, the profile; the coastal line of the White Cliffs of jasperware, the Edge of the Trees at Botany Bay and Port Jackson. Because what I would like to suggest through this lecture is that in the period between the late eighteenth century and the middle of the nineteenth century, over that couple of generations we might designate the Romantic Period, there appears, or possibly reappears, a discernible correlation between the geographical and the somatic, between science and sensibility, between empire and the skin. ${ }^{3}$ In other words, the 
visual cultures of this time demonstrate a preoccupation with measurement in relation to both land and people. The annexation of territory equates to the capture of likeness.

\section{$3: 36$}

While the following presentation deals primarily with the British imperial world, and very much from an Australian perspective, I start on the Continent. The first general maps of the Kingdom of France were produced for the Académie Royale des Sciences during the eighteenth century by four generations of the Cassini family: this vast undertaking took almost 60 years to complete, running from 1756 to 1815 (the surveys alone took more than 30 years), eventually producing a map of 182 sheets at a scale of $1: 86,400$. That's a total area of something like $12 \times 11 \frac{1 / 2}{2}$ metres. What was distinctive about the Cassini map (other than its Borgesian ambition) was its technical innovation: it was the first such project to be based on geodetic triangulation. The laws of plane trigonometry state that if you know precisely the length of one side of a triangle, its baseline, and the degrees of two of its angles, it is a straightforward matter to determine the other two sides and angle by mathematical calculation. Once this first triangle is established, it in turn can provide baselines for adjacent triangles, permitting infinite extension.

Indeed, during the 1780s an Anglo-French survey-suggested by the Comte de Cassini and conducted by General William Roy-established the relative positions of the observatories at Greenwich and Paris. Working with Jesse Ramsden's new theodolite, and with his more precise steel bar measuring chain replacing the old wire Gunter chain, Roy established the Hounslow Base Line, from which he was able to knit together the triangulations of the two nations just prior to the French revolution.

Such cartographic developments have evident parallels in the domain of art. Since the Renaissance recovery of classical geometry, artists had been using Pythagoras and Vitruvius to map not only the ideal body, but also specifically the ideal head.

\section{6:07}

Geometry is particularly helpful in facilitating the articulation of forms in space, and the conquest of perspective certainly enabled artists of the fifteenth and sixteenth centuries to describe location and structure with compelling veracity. But the proportional-symmetrical impulse, one might almost say imperative, also extended to the dramatis personae. As it always has, always will. From the canon of Polykleitos in the fifth century bc, with his famous declaration that "perfection comes about little by little, through many numbers", to the data-crunching software packages that underpin twenty-first century CGI figures, the human figure and face have long been subject to precise mathematical analysis and projection. 4 
So when the tools of mensuration were so prodigiously enhanced by concurrent advances in engineering, instrument-making, and science, or as it was then called, Natural Philosophy, right through the eighteenth century, it comes as no surprise to find technology applied to the making of likeness. Dibutades' simple tracing on a wall, or the freehand scissoring of a cut-paper shade portrait or silhouette, becomes perfectible and repeatable through the refinement and precision of the physionotrace. ${ }^{5}$ With this device, invented in 1784 by the French court musician Gilles-Louis Chrétien, the artist-or more correctly the operator, the mechanic-would follow the line of a profile shadow on a screen, while a pantograph system recorded the line on paper. In turn, and again with the aid of a pantograph, the image was then scaled down and transferred to a copper plate for printing. Working in partnership with a painter of miniatures, one Edmé Quéneday, in the twelve months from 1788 Chrétien produced no fewer than 850 physionotrace portraits.

Now this mechanical, labour-divisive, mass-reproductive function had significant political import. The accuracy of the profile was a virtual guarantee of likeness, and indeed, when Chrétien first began promoting his device in 1786, he suggested to the Académie that it might be used to record the images of new army recruits, a precautionary portraiture in case of future desertion. More importantly, the relative ease of production speeded up, demystified, de-skilled and hence democratised the whole process of face-making. In the early 1790s the physionotrace became a popular tool-not only for the production of cheap editions of portraits of political and theatrical celebrities, but also for the commissioning of portraits of members of the Third Estate: now working with another miniaturist, Jean Fouquet, Chrétien exhibited 100 engraved profiles at the Salon of 1793 (I'An II), and two years later no fewer than 600. The Cabinet des Estampes at the Bibliothèque Nationale holds something like 2,800 examples of the genre.

\section{9:44}

Unsurprisingly, the democratic confrères of the French across the Atlantic adopted the physionotrace with enthusiasm, although-as an image of the slave woman Flora attached to her sale document indicates-occasionally as much for Chrétien's surveillance purposes as for bourgeois portraiture. Initially the invention was promoted by expatriates such as Jean-Jacques Boudier in Philadelphia, and Charles de St-Mémin and Thomas de Valdenuit in New York, but soon enough it acquired a local accent, through a refinement of the mechanism by John Isaac Hawkins. Hawkins' machine, patented in 1802, was significantly different from Chrétien's model in that instead of tracing around a shadow with a pencil, it involved running a brass gnomon down the sitter's actual profile; it could even be operated by the sitter him or herself. Furthermore, instead of moving a pencil to produce an 
interim image prior to editioning, Hawkins' pantograph was connected to a steel point, which incised a line onto folded paper, which was in turn cut with scissors to produce a number of negative profiles.

The 'facie-trace' was an immediate success. Hawkins sold his invention to the entrepreneurial artist, soldier, scientist and politician Charles Willson Peale, who included it as an interactive in his Philadelphia museum. Access to the machine was included in your 25 cent admission, with just one penny extra for the paper, and scissors provided gratis. Or you could pay the freed Peale family slave, young Moses Williams, to cut it for you. At between 6 and 8 cents per portrait, Williams was soon enough able to afford to marry, and to buy a two-storey brick house. Peale estimated that in $1802,8,800$ profiles were taken-that is to say something like half of his visitors for that year availed themselves of the opportunity to take a sideways selfie. $\underline{6}$

The abstracting and indexical nature of this new physionotrace, and its phenomenal popularity, has prompted the American scholar Wendy Bellion to argue for a metaphoric equivalence (if not a causal relationship) between pictorial and political representation in America during the 1790s and 1800s. ${ }^{7}$ Immediately following the War of Independence, state legislatures were dominated by politicians with a shared conception of the national interest. However, as the independent federalist nation-state developed, and especially in response to the French Revolution, instead of depending on a landed, educated "natural aristocracy" (political leaders who could supposedly perceive and promote the communal good in the abstract), newly enfranchised US citizens preferred a clearer and more direct (if more local and partial) delegation of popular authority. As Bellion puts it, "each of these modes of representation stressed that the nature of the relation between a referent and its representative vehicle was to be exceedingly direct." $\underline{8}$

\section{$13: 18$}

If we take this metaphor into the third dimension-into sculpture-Bellion's suggested equivalence between the physical and the political can even be extended to encompass the philosophical and the moral. Here, the machine is not Hawkins' physionotrace, but the pointing machine, as developed by Nicolas-Marie Gatteaux (or possibly John Bacon) in the 1760s and perfected by Francis Chantrey (or his friend Antonio Canova) in the 1810s. An elaborate framework of wood and brass, needles and wing nuts, this device permits highly accurate translation and re-scaling of an original clay or plaster model into a finished work carved in marble.

It was the pointing machine that enabled the American sculptor Hiram Powers to produce six identical versions of his 1847 sculpture The Greek Slave. A highlight of the United States court at the Great Exhibition of 1851, this work was widely celebrated for its naturalism, one report claiming that it 
"outshines Madame Wharton [a contemporary tableau vivant performer] in the execution of poses plastiques." $\underline{9}$ First, there was its depiction of the female nude-shockingly naked, but idealistically conceived and modestly posed. Then, there was the broader truth to be found in its representation of the subjugation and abduction of Greeks by the Ottoman Turks during the War of Independence of the previous generation, and, by contemporary analogy, the oppression of African-American slaves on Southern plantations. As Elizabeth Barrett Browning put it:

They say ideal beauty cannot enter

The house of anguish. On the threshold stands

An alien image with enshackled hands, Called the Greek Slave! As if the artist meant her... .... To so confront man's crimes in different lands With man's ideal sense. Pierce to the centre,

Art's fiery finger! And break up ere long

The serfdom of this world... 10

Such was the fame of the sculpture that even before its London exhibition, Powers actually applied for a patent on the work. He well knew the capacity of his professional technology, manufacturing almost 200 versions of his 1843 bust of Proserpine, at various scales.

\section{$15: 55$}

Powers' compatriot Joel Hart also submitted a patent application, for what he called a "portrait-measuring invention from the life, having 200 steel needles". 11 The more points, the greater the accuracy. The more facts, the greater the truthiness. Out of this impulse to maximise the mathematics also comes the nineteenth-century obsession with craniometry, with the collecting and analysis of ethnic and criminal skulls, exemplified in Joseph Barnard Davis' Thesaurus Craniorum, with its 1,474 skulls and 25,000 individual measurements (and that was only in the first edition). But I am getting ahead of myself, both temporally and thematically...

The Enlightenment, Encyclopédiste, rationalist approach to face-making, as embodied in the physionotrace and the pointing machine, was reinforced in the late eighteenth and early nineteenth centuries by the Dutch surgeon and anatomist Pieter Camper. In 1770, Camper gave two lectures to the Amsterdam Drawing Academy in which he drew students' attention to the underlying structure of the skull, and to its variations from infancy to old age, from ape to Apollo. Following the lectures' delayed publication in 1791, 
Camper's analytic system gained wide currency, being reiterated in Charles White's 1799 Account of the Regular Gradation in Man, and in Different Animals and Vegetables.

The original lectures were intended primarily as an aid for artists, a response to the common failure of some painters to represent Balthazar, the African Magus, with convincing naturalism, and more broadly as a challenge to the conventionalised oval blocking of head shapes. By addressing the underlying osseous truths of human difference, Camper established in the so-called "facial angle" a geometric template or equation through which artists could describe "all sorts and conditions of men".

However, it was not long before Camper's empirical analysis began to attract and accrue secondary meanings. For Johann Caspar Lavater, the Swiss pastor and poet, differences in physiognomy indicated not merely distinctions of age or race, but were a reflection of a person's inner life and fundamental character. Riffing on the Italian Renaissance scholar Giambattista della Porta's De humana physiognomica (1586), with its matching of human and animal characteristics, Lavater's Physiognomische Fragmente suggested that temperament-the old doctrine of the four humours-was visible and legible in the "constitution, the form and the curvature of the scull", and in the shape, position, and relative dimensions of eyes, ears, noses, and so forth. $\underline{12}$

\section{9:16}

Perhaps most significantly, Lavater's ideas were quickly adopted and adapted by the German physician Franz Josef Gall, in the practice he called "organology", but which was subsequently denominated "phrenology" by Gall's former assistant and disciple Johann Spurzheim. This study was actually based on an accurate intuition, that is, that the several distinct parts or regions of the human brain-the brain stem, the cerebellum, and the four lobes of grey matter that make up the cerebral cortex-have distinct and separate functions, and Gall's underlying thesis is in fact strongly supported by modern neuroscience and advanced medical imaging.

Ultimately, however, phrenology's pretensions to scientific validity are totally undone by several false assumptions: that the size of a particular "organ" or region of the brain determines its capacity; that the external bony carapace of the skull is a direct extension or reflection of the state of the soft tissue beneath, and finally, by a topography which maps temperamental inclination and potential skill sets-or in phrenological jargon "propensities", "feelings", "perception", and "reflexivity"-as if they were one and the same.

Many contemporaries diagnosed these flaws immediately. Phrenology was investigated and dismissed as unscientific as early as 1808, by a committee of the Institut de France chaired by Georges Cuvier. It was condemned by the 
Edinburgh Review in 1805 as "a piece of thorough quackery from beginning to end", and it was mocked mercilessly and repeatedly by Regency

caricaturists. $\underline{13}$ Nevertheless, this pseudo-science continued to maintain and extend its popularity throughout the nineteenth century and even into the twentieth. Its adherents including many who should have known better, amongst them the scientist Alfred Russel Wallace, the inventor Thomas Alva Edison, poet Ralph Waldo Emerson, even four-times British prime minister William Ewart Gladstone. Perhaps it is just that people with insistent, bumpy middle names were particularly susceptible.

Belief in the system was as wide as it was high. The discipline's classic English-language text, The Constitution of Man, by the Scottish lawyer George Combe, sold 350,000 copies between its publication in 1828 and 1900-an average of 5,000 copies per year, and seven times the sales of Darwin's Origin of Species. Phrenology even enjoyed a twentieth-century revival in the United States; at the 1924 kidnapping and murder trial of Nathan Leopold and Richard Loeb, the court was shown phrenology cards, with the defendants' "propensities" clearly written in their profiles.

Of course, the Australian colonies were not immune, either; our own prime ministers Alfred Deakin and George Reid both had their heads read at different times. When in 1838 the convict artist Thomas Bock was commissioned to draw a portrait of Jane, Lady Franklin, wife of the Governor of Van Diemen's Land, the sitter wrote to her sister:

... would you believe it that I am having my portrait taken again to please Mrs McConochie ... This time I am to be without a cap, and it is three quarters face in that position which is to bring to light very conspicuously, by Mrs McConochie's express desire, my two great bumps of causality. 14

While in the colony of Victoria in 1855, the Select Committee on Aborigines commissioned a report on the heads of the Kulin nation from local practitioner Philemon Sohier.

\section{3:22}

A few years later, in 1859, the prominent colonial phrenologist Archibald Sillars Hamilton gave an extensive series of lectures in Sydney which included, inter alia, character studies of the Governor, Sir William Denison, and of John Bede Polding, the Roman Catholic Archbishop. ${ }^{15}$ Further, working from the evidence of Edwin Dalton's recent composite photograph of the Legislative Assembly, Hamilton confidently declared that some of the politicians had "brains so formed as to disqualify them from putting 
themselves forward as lawmakers for the people." $\underline{16}$ But then Hamilton's attitude to the law was somewhat ambiguous. The following year, he was charged with incitement to grave robbing, in a case involving the heads of two prisoners recently executed at Maitland jail-the skull of Wonnarua Aboriginal man Jim Crow was returned to his people for burial as recently as 2015. 17

The pseudo-science of phrenology appealed to the Romantic era because it brought together the senses of vision and touch, and because-like palmistry or astrology-it seemed able to integrate the subjectivity of boundless emotion and the objectivity of measurable dimension. In the physionotrace or pointing machine, we have an instrument which preserves and effectively translates data from one form to another, that is, from a 3D living subject to a 2D graphic analogue, or from a plaster model to a reduced or enlarged stone replica. In phrenology, the intention, the ambition, is likewise to convert the data from one form to another, but here it is from a set of empirical facts to the abstract domain of values, of personal, moral, emotional, spiritual engagement.

Furthermore, phrenology's apparent validity was enhanced by its easy-toread graphic manifestations. The organic divisions of the phrenological model head or chart presented the various mental faculties as administrative divisions within a wider polity of identity and character, in a way analogous to the counties and parishes of England, or, for that matter, of New South Wales, or indeed, to the nation-states that constituted Europe. At the same time, in the storage and display of skulls and plaster casts and in the tabulation of cranial measurements, there was a comforting regularity. The literal collectors of heads and their metaphoric companions, those bookbreaking, extra-illustrating hobbyists who filled their volumes of James Granger's Biographical History of England with engraved portraits of historical worthies, held the intemperance of character and behaviour in check, sealed within the geometric matrix of the table, the shelf, the box, the book. 18

\section{6:31}

This is a matter worth further consideration. According to convention, most portraits (other than miniatures) were painted on quadrilateral supports, and throughout the eighteenth and nineteenth centuries, indeed, until James Whistler's radical "Arrangement in white and yellow" and "Arrangement in flesh colour and grey" in the 1880s introduced colour and air into painting display, it was usual for pictures at exhibitions to be shown jammed up tight, frame abutting frame. Juggling the competing claims of excellence, genre, scale, and symmetry (not to mention patronage and lobbying), exhibitions at 
the Paris Salon or London's Royal Academy ended up presenting varieties of plaster-gilt grids-not entirely regular, of course, but essentially a territory of canvas divided into preferential physiognomic and corporeal allotments. $\underline{19}$

Concurrently, as we have seen, the grotesque wall paintings of imperial Rome, and especially those uncovered at Herculaneum and Pompeii, served as models for neo-classical interiors, and their assertive rectilinearity was widely adopted not only in the formal paint-and-plaster designs of Robert Adam, but also in the contemporary ephemeral practice of pasting prints directly onto the wall. At Calke Abbey, Derbyshire, the eccentric Sir Henry Crewe, the 7th Baronet, stuck up caricatures, filling an entire room, and there is another such survival at Rokeby Hall, County Durham. When, after the collapse of his marriage in 1816, the aristocrat, poet, and exemplary Regency buck George Gordon Byron, Baron Byron put his library up for auction before departing for Italy, the catalogue included a portable print medley: "a screen covered with portraits of actors, pugilists, representations of boxing matches etc." $\underline{20}$

In their interior paste-ups, these amateurs were replicating, or echoing, at least, not only the traditional Academic hang, but also the natural habitat of late Georgian caricature, the London print-shop. In numerous contemporary etchings and engravings, we see crowds of gossip-gawkers and/or individual victims of the satirist's burin, standing before print shop windows-Hannah Humphrey's or Samuel Fores', William Holland's or William Hone's, indulging in that free metropolitan entertainment known as "picture-fuddling". ${ }^{21}$ Like the ranks of natural history specimens in the vitrines of Sir Ashton Lever's Holophusikon, mocking depictions of English politicians, aristocrats, churchmen, military commanders, actresses, sportsmen, criminals, and other public characters were shown in close array for public amusement and discussion (and hopefully purchase), one in each pane of glass.

Capturing, squaring up, enclosing-these are functions of observation and representation as much as they are of conquest and property development. $\underline{22}$ So perhaps the most secure location for portraiture is within portraiture itself.

\section{9:55}

What do I mean by this? Well, it is common practice for beggars to avoid the necessity for verbal complaint by displaying a written sign indicating the nature of their affliction or the extent of their need. Paul Strand's photograph Blind Woman is a particularly memorable example of this kind of advertising, and the whimsically, ironically, or topically re-worded placard next to the donations hat became a favourite device of twentieth-century cartoonists. In 2005, Finnish artist Jani Leinonen presented an installation entitled I Want to 
Get Rid of Class Distinction but All I Think and Do is a Result of Class Distinction, which consisted entirely of roughly scrawled placards he had purchased from beggars around the world.

This auto-advertising was already a regular practice amongst the street people of Georgian and Regency Britain. One of the characters described in John Thomas Smith's account of London beggary, Vagabondiana, is a charlatan-"a foreigner, and probably a Frenchman"-who "throws up his eye-balls" in pretence of blindness. Smith notes that this man:

is now and then detected, in consequence of a picture, which is painted on a tin plate, and fastened to his breast, being the portrait of and worn many years ago by a marine, who had lost his sight at Gibraltar. 23

Likewise, in a portrait by itinerant miniaturist John Dempsey of Billy the Match Man of Liverpool, we can see hanging around the man's neck a placard on which is pasted a pair of silhouettes, with text beneath.

Remarkably, these would appear to be copies of a silhouette, in all likelihood also by Dempsey, contained in a miscellany of Liverpudlian character profiles compiled around 1830. It would seem that Dempsey's 1844 portrait of this man is actually his second, and that Billy is wearing the first, drawn and printed some 15 years previously.

Or, to locate this same phenomenon in the colonial setting, there is William Fernyhough's silhouette of Jemmy Piper, the Wiradjuri man who served as a guide and Indigenous go-between on surveyor Major Thomas Mitchell's 1836 expedition into the interior. This lithograph was evidently issued by local printer Thomas Austin in December 1836, to capitalise on popular interest following the Mitchell party's return to Sydney in the previous month. It shows Piper as subaltern "mimic man", in cast-off European clothes, wearing - as Mitchell would later recall- "my own red coat and ... a cocked hat and feather which had once belonged to Governor Darling." $\underline{24}$ Not long afterwards, Austin offered a portrait of the Major himself as an extension to Fernyhough's earlier series "Military and Editorial Sketches", in which the sitter's Wellingtonian profile addresses a copy of what is clearly the Piper print.

33:06

This could be a relatively simple master-servant trope. Alternatively, it may signify a public farewell to Mitchell on his departure from the colony, or, as Elisabeth Findlay has argued, a deliberate attempt to rehabilitate his reputation following a public enquiry and press commentary arising from the killing of Aborigines at Dispersion Creek during the expedition. ${ }^{25}$ Whatever 
the case, the work's reiterative, almost recursive nature, its in-line advertising, if you like, functions as does Dempsey's portrait of Billy the Match man, emphasising both the accuracy and the artifice, the whole abstract, geometric dimension of portraiture in the early nineteenth century. Mitchell with Piper might not be Aristotle Contemplating the Bust of Homer, but it is not far from Hamlet with the skull of Yorick, and very close to the phrenologist and his tools of trade. Mitchell was, after all, a surveyor: a definer of property, an explorer and explainer of space, a ruler of lines and a former of squares.

The compartmentalising tendency in British social relations, the ingrained habits of survey and enclosure, is famously, Whiggishly expressed in George Cruikshank's British Beehive of 1867 (from an idea first sketched in 1840), a print which was subsequently re-issued with the title $A$ Penny Political Picture for the People. The royal family may be at the summit of this humming polity, but there are more than fifty other cells in the hive, not only a variety of trades and professions, but also more abstract domains such as the constitution, the rule of law, and freedom of religion and of the press, while the whole edifice rests on a foundation of an imperial military and, as the sign proclaims, the "bank of the richest country of the world".

Despite a moral gloss, this is also the class ideology implicit in both the look and the dynamics of Edward Wallis' 1825 children's board game, Every Man to his Station, in which charity and modesty are rewarded by social advance, while slothfulness or theft see you sent to the House of Correction. In the real world of Regency Britain, such transgressions often actually meant transportation to Australia.

And here we find the ultimate identity warehouse: the Benthamite panopticon architecture of the 1849 "Separate Prison" at Port Arthur. Hooded, de-socialised, alienated, Van Diemen's Land's "worst of the worst" entered the Penitentiary Chapel separately, and took their places in individual, isolated, side-screened pew-stalls. $\stackrel{26}{ }$ From the point of view of the Chaplain and the Commandant, the refractory, recidivist convicts were here pacified, homogenised, contained and made manageable by the simple device of framing.

\section{$36: 26$}

As for class, so for race; from the same period, there is the manner of display of George Catlin's 300 portraits of Native North Americans, as presented at the Egyptian Hall, Piccadilly, between 1840 and 1845. All three-quarter lengths, Catlin's pictures completely covered the walls of the exhibition room: an acrostic of the exotic, a table of tribes, a geometric containment of the vastness of the New World. Later in the century, we see the same regulation of Indigenous people in Charles Walter's disciplined array of photographs of Aborigines at Corranderrk, shown at the Melbourne 
Intercolonial Exhibition of 1866-1867, and in the two-inch chequerboard backgrounds of anthropometric photography, as recommended by Jones Lamprey, Assistant Secretary of the Ethnological Society of London in 1869. Later still, we have the quadrangular display of Prince Roland Bonaparte's photographic collections in the early years of the twentieth century. $\underline{27}$

Again, there is an implicit association here between the mapping of imperial expansion-the framing grid evoking lines of longitude and latitude-and the mapping of the Indigenous body. James Ryan tells a nice story about the explorer, scientist, and eugenicist Francis Galton working in 1852-1854 amongst the Nama people of present-day Namibia and Botswana. The steatopygous (fat-storing) buttocks of sub-Saharan desert women were objects of intense fascination for the scientific gentlemen of the early nineteenth century. The celebrated Saartjie Baartman was the subject of the first chapter and first two plates of Hilaire and Cuvier's 1824 Natural History of Mammals, and another "Hottentot Venus" was exhibited nude in Paris five

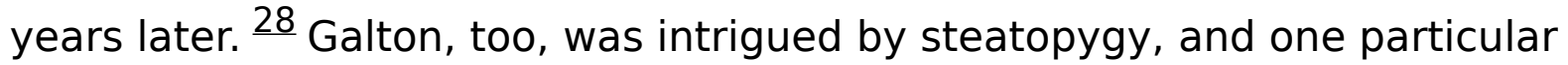
Nama beauty left him "perfectly aghast at her development". However, although "anxious to obtain accurate measurements of her shape", he was constrained by a Victorian sense of delicacy. His solution was to measure the woman at a distance, taking observations with his sextant and converting them using tape, trigonometry, and logarithms. $\underline{29}$

Less frivolously, we might also remember the Noongar warrior Yagan, murdered by a settler in 1833 for government reward money, his head cut off, smoked to preserve it, then sent as an ethnological specimen to the Liverpool Institute's museum in England. When it became seriously decomposed in the middle of last century, the head was placed in a plywood box, together with the head of a Maori and a mummy from Peru; all three were buried in Everton cemetery. The remains were exhumed in 1977, and Yagan was finally put to rest on his country in 2010. In a poignant note in his diary, settler George Fletcher Moore records his encounter with the awful object. He draws Yagan's head in profile, and beneath it writes: "I could not get his head out of my head till I put it on paper." In an inked-in square within the rectangle of the page. $\underline{30}$

40:07

Finally, perhaps the ultimate demonstration of the collision and incompatibility of rhizomic, dreaming Aboriginality and four-square settler surveying (or, if you like, of Makarrata treaty 31 and constitutional preamble) can be found in The Aboriginal Puzzle of Australia, a turn-of-the-twentiethcentury jigsaw-joke in which the direction to "make a complete figure out of the four portions" is, quite simply, impossible. 
So let us think outside the square for just a moment. Allow me to digress or rather diverge momentarily, into the domain of physics and geology. In 1774, following a suggestion made almost a century previously by Isaac Newton in the Principia, Astronomer Royal Nevil Maskelyne attempted to calculate the mean density of the earth (and hence a value for Newton's gravitational constant) by measuring the deflection of a pendulum caused by the mass of a nearby mountain. With sponsorship from the Royal Society and its wonderfully named Committee of Attraction, Maskelyne spent three months living in the wilds of the Scottish Highlands in order to map Schiehallion, the eminence most appropriate (because most regularly shaped) for the purposes of the experiment. Maskelyne's companion in the survey was the mathematician Charles Hutton, whose system for representing the mountain's volume involved plotting a series of concentric lines linking points of equal elevation around the mountain's circumference-what we now know as contour lines. $\frac{32}{2}$ These were not the earliest contour lines in the European cartosphere. As early as 1701, Edmund Halley had connected points of equal value on his map of magnetic declination-that is, the difference between geographical and magnetic North Poles-in the Atlantic Ocean. And with regard to topographical measurement, Domenico Vandelli had mapped the Duchy of Modena in 1746, while Philippe Buache had traced the submarine gradient of the English Channel in a chart published in 1752. Nevertheless, Maskelyne and Hutton's were certainly the first in Britain.

Of course, the device of curvilinear parallels was not completely unfamiliar in the United Kingdom. Celtic spirals were being recorded by contemporary antiquarians and Claude Mellan's 1649 Sudarium, engraved in a single-line expanding spiral, was well known amongst print connoisseurs of the eighteenth and nineteenth centuries.

Then there are fingerprints. In 1788, Johann Mayer published a volume of Anatomical Copper-Plates with Appropriate Explanations, which illustrated in fine detail the whorls, loops, and arches of the ridge structure of human fingerpads. A generation or so later, the Dutch physician Johannes Purkinje identified nine distinct types of these so-called papillary lines. Thomas Bewick probably deserves a place in this paper simply on account of the tailpiece in Volume 1 of British Birds with its image of the Corinthian Urinator. But there is another vignette later in the same volume which is even more intriguing. Over the top of The Returning Cottager, a tiny wood engraving of a rural landscape with a house and a horseback figure, Bewick has overlaid an actual size trompe l'oeil of his fingerprint. And some years later, the frontispiece of his 1818 Aesop's Fables includes both mock-hand-inscription and mock-thumbprint. 
$44: 12$

Other natural philosophers also described linear structures beneath the surfaces of nature: the bulging striations of musculature in academic écorchés and medical illustrations, for example, or the rippling terrestrial strata illustrated in geologist Charles Lyell's Principles of Geology and Elements of Geology. $\frac{33}{3}$ The currency of the ripple-curve was thus increased through the first half of the nineteenth century, until 1843, when the conventional "hairy caterpillar" hatching indicating mountains and hills finally disappeared from all the maps prepared by the Ordnance Survey of Great Britain, to be replaced by contour lines, and until the 1850s, when William Herschel, a British magistrate in Bengal, introduced the use of handprints and fingerprints to police the authenticity of signatures on contracts and government documents.

This $2 \mathrm{D}$ rendering of $3 \mathrm{D}$ objects brings me to another dimension of the story of Dibutades that I did not mention at the beginning of this essay. In Pliny's account, Dibutades is the daughter of Butades, a potter, and her father, sympathising with the girl's distress and much taken with her graphic invention, fills in the profile she has drawn, modelling her lover's face in clay, which he then bakes in the kiln with his vessels. $\frac{34}{1}$ Thus, in the one myth, we have not only the invention of drawing, or painting, but also of relief ceramic sculpture.

Josiah Wedgwood, who commissioned Wright of Derby's version of the story in 1782, was well aware of the connection to his business, particularly the portrait busts he had been producing since the 1760s, both monochrome heads in black basalt and the moulded, sprigged coloured jasperware of subsequent decades. In quiet tribute both to Butades and to his much later, industrial-revolutionary successor, Wright includes in his painting the chiaroscuro detail of a white-hot pottery kiln firing away in the room on the right of the picture.

Here then we have a close equivalent to the shade portrait, but one which also has depth: historical depth, in its reference to Classical and Renaissance cameos, medals, and relief sculpture, and depth of resemblance through a close modelling of features which invokes both popular waxworks and the indexical life-cast or death mask. For all British art history's conventional emphasis on the members and exhibitions of the Royal Academy and on associated literary commentary, we must remember that the deliberate interchange or unconscious slippage between exclusive and popular media, between marble and Parian Ware, silver and pewter, onyx and china, between England and the colonies, is substantial, intense, and complex in this period. 
47:19

The Wedgwood medallions' simple, actual, physical, three-dimensional depth is also a direct reflection of their medium, their material.

In November 1788, Arthur Phillip sent to Sir Joseph Banks in London a gift of clay from Sydney Cove. It had been commended to the Governor by the Abbé Mongez, one of the naturalists on La Pérouse's ill-fated Astrolabe expedition, which called at Port Jackson just a week after the arrival of the First Fleet. Mongez believed New South Wales had some practical, commercial potential in the manufacture of earthenware, or even china. Banks in turn sent the marl to his friend Wedgwood, who declared it "an excellent material for pottery". ${ }^{35}$ He commissioned his draughtsman Henry Webber to design a commemorative plaque, the now-famous Sydney Cove Medallion, also known as Hope encouraging Art and Labour, under the influence of Peace, to pursue the employments necessary to give security and happiness to an infant settlement.

While the ethereal concept and figures of the medal are resolutely European and Classical, we should remember that in bringing the material to Banks' attention, Phillip specifically noted that this same clay was that "with which the Natives mark themselves". $\underline{36}$

What the Governor could not know (especially given the early reluctance of the Australians to engage with the invaders) was that the body decorations of the Eora were directly linked to country, not only through the materials employed, the blood and bone of red ochre and pipeclay, but also through their designs' reference to totemic ancestors and narratives.

In other words, for Aboriginal Australians, the portrait is the map. $\underline{37}$

What is passing strange is that the forms through which Aboriginal people declared their belonging to country and hence, through the stories and ceremonies associated with country, their personal, individual identities have a striking resonance with the wobbly contours of settler Australians' survey maps. Whether in the weapons and tools of the Ngarrindjeri of the lower Murray, or in body paint amongst the Barkindji on the Darling, in the Wiradjuri dendroglyphs of the central west of New South Wales, in the ceremonial feather-lined isobars of the Arrernte of Central Australia, or in the much more recent eye candy of Pintubi artist George Tjungurrayi, the 65,000 year old visual culture of the Aboriginal Australians makes strange, imperfect intersection with European ways of writing place and identity. 
$50: 18$

Now you may be thinking that the foregoing Sebaldesque meander and this concluding flurry of Aboriginalism tells us little about portraiture; that shadow and profile, squares and contours, phrenology and cartography are at best tangential matters.

So let me finish, then, with a clue, or at least a bump of causality, a point of connection from a few decades beyond this essay's temporal envelope, an indication that underlying this loosely associated material there are perhaps some perceptual and conceptual fundamentals. Charles Conder's 1889 sketch An Impressionist is a portrait of the leader of the Australian naturalist painters of the 1880s, and in many ways the greatest face-maker of Marvellous Melbourne, Tom Roberts. First, let me remind you that as a young man Conder worked for his uncle William on the New South Wales Lands Department's trigonometrical survey. Now look at the painting. Note how, echoing the angular dynamic of Roberts' arm and leg akimbo, the artist introduces a complementary pattern: a period-appropriate, decorative-linear proto-art nouveau zigzag. If you look closely, you will see it is a surveyor's Gunter chain.

\section{Footnotes}

1 Robert Rosenblum, "The Origin of Painting: A Problem in the Iconography of Romantic Classicism", Art Bulletin 39, no. 4 (December 1957), 279-290.

2 Rosenblum, 'The Origin of Painting”, 284.

3 In The Art of Describing: Dutch Art in the Seventeenth Century (Chicago, IL: University of Chicago Press, 1983), Svetlana Alpers notes intriguing Early Modern artistic precedents for the juxtaposition of place and face: Petrus Apianus' illustrations to Ptolemy's Cosmographia (1551) and (especially) Johannes Vermeer's The Art of Painting (1666-68). See Chapter 4, "The Mapping Impulse in Dutch Art", esp. 165-168.

$4 \quad$ As quoted by the third-century bc Philo Mechanicus of Byzantium in his Syntaxis; see J.J. Pollitt, The Art of Ancient Greece: Sources and Documents (Cambridge: Cambridge University Press, 1990), 77.

5 Tom Halliday, Facing the Public: Portraiture in the Aftermath of the French Revolution (Manchester: Manchester University Press, 2000), 43-47.

6 Gwendolyn DuBois Shaw, “'Moses Williams, Cutter of Profiles': Silhouettes and African American Identity in the Early Republic", Proceedings of the American Philosophical Society 149, no. 1 (March 2005): 23-39.

7 Wendy Bellion, "The Mechanization of Likeness in Jeffersonian America", paper presented at Media in Transition conference, Massachusetts Institute of Technology, 8 October 1999, http://web.mit.edu/m-i-t/articles/bellion.html. Accessed 18 March 2019. See also Wendy Bellion, "Heads of State: Profiles and Politics in Jeffersonian America", in Lisa Gitelman and Geoffrey B. Pingree (eds), New Media, 1740-1915 (Cambridge, MA: MIT Press, 2003), 31-59.

8 Bellion, "The Mechanization of Likeness in Jeffersonian America".

9 The Times, 9 June 1851, 4.

10 Elizabeth Barrett Browning, “Hiram Powers' Greek Slave”, first published in Household Words, 26 October $1850,99$. The American analogy is made explicit in a contemporary drawing by John Tenniel: The Virginian Slave. Intended as a Companion to Power's [sic] "Greek Slave", Punch, 7 June 1851, 236. See also Martina Droth, Jason Edwards, and Michael Hatt (eds), Sculpture Victorious: Art in an Age of Invention, 1837-1901 (New Haven, CT: Yale University Press, 2014), 242-254, 308-327.

11 The Will of Joel T. Hart, dated 18 February 1877, cited in Donald Williamson, "From Florence to Frankfort: The Reinterment of Joel Tanner Hart", Proceedings of the Fifth City and the Book International Conference, Florence, 11 October 2008. www.florin.ms/CBV.html.

12 Joan K. Stemmler, "The Physiognomical Portraits of Johann Caspar Lavater", Art Bulletin 75 no. 1 (March 1993), 156. See also Michael Shortland, "The Power of a Thousand Eyes: Johann Caspar Lavater's Science of Physiognomical Perception", Criticism 28, no. 4 (fall 1986): 379-408.

13 John Gordon, "The Physiognomical System of Drs Gall and Spurzheim, \&c.", The Edinburgh Review 25 no. 49, 1 June $1815,227-268$. 
14 Jane Franklin to Mary Simpkinson, 21 June 1838, Royal Society MSS, Franklin Papers RS 16/10, University of Tasmania Archives, Hobart.

15 John Bede Polding was actually the first Roman Catholic (not Anglican) Archbishop of Sydney.

16 Archibald Sillars Hamilton, "Parliamentary Phrenology", The Empire (Sydney), 7 November 1859, 8.

17 Simon Lauder, “Indigenous Man's Skull Returns to his People More Than 150 Years after its Theft", P.M., ABC Radio National, 29 June 2015, www.abc.net.au/pm/content/2015/s4264011.htm. Accessed 26 October 2019.

18 Lucy Peltz, Facing the Text: Extra-Illustration, Print Culture and Society in Britain 1769-1840 (San Marino: The Huntington Library, Art Collections and Botanical Gardens, 2017).

19 David H. Solkin (ed.), Art on the Line: The Royal Academy Exhibitions at Somerset House 1780-1836 (New Haven, CT: Yale University Press, 2001).

20 Thomas Moore (ed.), Works of Lord Byron; with his Letters and Journals, and his Life (London: John Murray, 1833), Vol. 3, 226.

21 "Amusements of the Moneyless", Chambers' Journal of Popular Literature, Science and Arts no. 72, 19 May $1855,307$.

22 Marcia Pointon is as definitive here in relation to the British Long Eighteenth Century as is Svetlana Alpers with the Dutch Golden Age. See Marcia Pointon, Hanging the Head: Portraiture and Social Formation in Eighteenth-Century England (New Haven, CT: Yale University Press, 1998), Chapter 1, "Spaces of Portrayal", Part I, "Hanging and Framing", 12-36.

23 John Thomas Smith, Vagabondiana; or, Anecdotes of Mendicant Wanderers Through the Streets of London with Portraits of the Most Remarkable Drawn from Life (London: the proprietor, 1817), 25-26.

24 Thomas Mitchell, Three Expeditions into the Interior of Eastern Australia; with Descriptions of the Recently Explored Region of Australia Felix, and of the Present Colony of New South Wales, 2 vols (London: T.W. Boone, 1839), Vol. 2, 338-339.

25 Elisabeth Findlay, "Peddling Prejudice: A Series of Twelve Profile Portraits of Aborigines of New South Wales", Postcolonial Studies 16, no. 1 (2013): 2-27.

26 Recalling US Secretary of Defense Donald Rumsfeld's description of Guantanamo Bay detainees at a press conference 22 January 2002.

27 George Gurney and Therese Thau Heyman, George Catlin and his Indian Gallery, (Washington, DC: Smithsonian American Art Museum, 2002); Jane Lydon, Eye Contact: Photographing Indigenous Australians (Durham, NC: Duke University Press, 2005), Chapter 1, “'This Civilising Experiment': Charles Walter, Missionaries and Photographic Theatre", 33-72.

28 Étienne Geoffroy Saint-Hilaire and Frédéric Cuvier, Histoire naturelle de mammifères: avec des figures originales, coloriées, dessinées d'après des animaux vivan [Natural History of Mammals] (Paris: A. Belin, 1824).

29 James Ryan, Picturing Empire: Photography and the Visualization of the British Empire (London: Reaktion Books, 1997), 144.

30 George Fletcher Moore, Original Letters and Journals, J.S. Battye Library of West Australian History, mf263a, 15 July 1833.

31 For information on the Makarrata Agreement, please see to the Northern Territory Government's page on the Makarrata Agreement, at: https://dtsc.nt.gov.au/arts-and-museums/northern-territory-archives-service/cabinetrecords/1981-records/makarrata-agreement.

32 Karen Rann and Robin S. Johnson, "Chasing the Line: Hutton's Contribution to the Invention of Contours", Journal of Maps, March 2019, doi: 10.1080/17445647.2019.1582439. Accessed 26 October 2019.

33 Charles Lyell, Principles of Geology, 3 vols (London: John Murray, 1830-1833); and Charles Lyell, Elements of Geology (London: John Murray, 1838).

34 Although in some accounts Butades is the potter who is sometimes called Dibutades and his daughter's name is Kora, here the author was working from Rosenblum, who states that the girl was "generally referred to as Dibutades, after her father's name", see "The Origin of Painting", 281.

35 Josiah Wedgwood to Sir Joseph Banks, 12 March 1790, in "On the analysis of a mineral substance from New South Wales...", Philosophical Transactions of the Royal Society of London, Vol. 80, Art. XVII, 1790.

36 Governor Arthur Phillip to Sir Joseph Banks, 16 November 1788, Sir Joseph Banks Papers, series 37 no. 8, State Library of New South Wales, Sydney.

37 Krim Benterrak, Stephen Meucke, and Paddy Roe, Reading the Country: Introduction to Nomadology (Fremantle: Fremantle Arts Centre Press, 1984).

\section{Bibliography}

Alpers, Svetlana (1983) Art of Describing: Dutch Art in the Seventeenth Century. Chicago, IL: University of Chicago Press. Bellion, Wendy (1999) "The Mechanization of Likeness in Jeffersonian America". Paper presented at Media in Transition conference, Massachusetts Institute of Technology, 8 October, http://web.mit.edu/m-i-t/articles/bellion.html. Accessed 18 March 2019. 
Bellion, Wendy (2003) "Heads of State: Profiles and Politics in Jeffersonian America”. In Lisa Gitelman and Geoffrey B. Pingree (eds), New Media, 1740-1915. Cambridge, MA: MIT Press, 31-59.

Benterrak, Krim, Meucke, Stephen, and Roe, Paddy (1984) Reading the Country: Introduction to Nomadology. Fremantle: Fremantle Arts Centre Press.

Chambers' Journal (1855) "Amusements of the Moneyless". Chambers' Journal of Popular Literature, Science and Arts no. 72 , 19 May, 307.

Droth, Martina, Edwards, Jason, and Hatt, Michael (eds) (2014) Sculpture Victorious: Art in an Age of Invention, 1837-1901. New Haven, CT: Yale University Press.

DuBois Shaw, Gwendolyn (2005) “'Moses Williams, Cutter of Profiles': Silhouettes and African American Identity in the Early Republic". Proceedings of the American Philosophical Society 149, no. 1 (March): 23-39.

Findlay, Elisabeth (2013) "Peddling Prejudice: A Series of Twelve Profile Portraits of Aborigines of New South Wales". Postcolonial Studies 16, no. 1: 2-27.

Geoffroy Saint-Hilaire, Étienne and Cuvier, Frédéric (1824) Histoire naturelle de mammifères: avec des figures originales, coloriées, dessinées d'après des animaux vivan [Natural History of Mammals]. Paris: A. Belin.

Gordon, John (1815) “The Physiognomical System of Drs Gall and Spurzheim, \&c.". The Edinburgh Review 25 no. 49,1 June, 227-268.

Granger, James (1804) A Biographical History of England: From Egbert the Great to the Revolution, 4th edn. London: W. Nicholson.

Gurney, George and Thau Heyman, Therese (2002) George Catlin and his Indian Gallery. Washington, DC: Smithsonian American Art Museum.

Halliday, Tom (2000) Facing the Public: Portraiture in the Aftermath of the French Revolution. Manchester: Manchester University Press.

Hamilton, Archibald Sillars (1859) "Parliamentary Phrenology". The Empire (Sydney), 7 November, 8.

Lauder, Simon (2015) “Indigenous Man's Skull Returns to his People More Than 150 Years after its Theft”. P.M., ABC Radio National, 29 June, www.abc.net.au/pm/content/2015/s4264011.htm. Accessed 26 October 2019.

Lydon, Jane (2005) Eye Contact: Photographing Indigenous Australians. Durham, NC: Duke University Press.

Lyell, Charles (1830-1833) Principles of Geology, 3 vols. London: John Murray.

Lyell, Charles (1838) Elements of Geology. London: John Murray.

Mitchell, Thomas (1839) Three Expeditions into the Interior of Eastern Australia; with Descriptions of the Recently Explored Region of Australia Felix, and of the Present Colony of New South Wales, 2 vols. London: T.W. Boone, Vol. 2.

Moore, George Fletcher (n.d.) Original Letters and Journals, J.S. Battye Library of West Australian History, mf263a, 15 July 1833.

Moore, Thomas (ed.) (1833) Works of Lord Byron; with his Letters and Journals, and his Life, Vol. 3. London: John Murray.

Peltz, Lucy (2017) Facing the Text: Extra-Illustration, Print Culture and Society in Britain 1769-1840. San Marino: The Huntington Library, Art Collections and Botanical Gardens.

Pointon, Marcia (1998) Hanging the Head: Portraiture and Social Formation in Eighteenth-Century England. New Haven, CT: Yale University Press.

Pollitt, J.J. (1990) The Art of Ancient Greece: Sources and Documents. Cambridge: Cambridge University Press.

Rann, Karen and Johnson, Robin S. (2019) "Chasing the Line: Hutton's Contribution to the Invention of Contours". Journal of Maps, March, doi:10.1080/17445647.2019.1582439. Accessed 26 October 2019.

Rosenblum, Robert (1957) "The Origin of Painting: A Problem in the Iconography of Romantic Classicism". Art Bulletin 39, no. 4 (December): 279-290.

Ryan, James (1997) Picturing Empire: Photography and the Visualization of the British Empire. London: Reaktion Books.

Shortland, Michael (1986) “The Power of a Thousand Eyes: Johann Caspar Lavater's Science of Physiognomical Perception”. Criticism 28, no. 4 (fall): 379-408.

Smith, John Thomas (1817) Vagabondiana; or, Anecdotes of Mendicant Wanderers Through the Streets of London with Portraits of the Most Remarkable Drawn from Life. London: the proprietor.

Solkin, David H. (ed.) (2001) Art on the Line: The Royal Academy Exhibitions at Somerset House 1780-1836. New Haven, CT: Yale University Press.

Stemmler, Joan K. (1993) "The Physiognomical Portraits of Johann Caspar Lavater". Art Bulletin 75 no. 1 (March), 156.

Williamson, Donald (2008) "From Florence to Frankfort: The Re-Interment of Joel Tanner Hart", Proceedings of the Fifth City and the Book International Conference, Florence, 11 October. www.florin.ms/CBV.html. 


\section{Licensing}

The Publishers of British Art Studies are committed to supporting scholarship on British art and architecture of all periods. This publication is made available free of charge at https://www.britishartstudies.ac.uk. We ask users to identify the use of materials made available through this website and to provide an appropriate credit to the to the author and the publication, so that others may find and use our resources.

Except where otherwise noted, this work is licensed under a Creative Commons Attribution-NonCommercial 2.0 UK: England \& Wales Licence (CC BY-NC 2.0 UK). To view a copy of this license, visit https://creativecommons.org/licenses/by-nc/2.0/uk/ or send a letter to Creative Commons, PO Box 1866, Mountain View, CA 94042, USA.

The Publishers fully support the protection of intellectual property and are committed to complying with, and strictly adhering to, all applicable copyright law. In many cases, copyright or other proprietary rights may be held by individuals or entities other than, or in addition to, the Publishers. If a work or a photographic image is still protected by copyright, you must cite the relevant copyright information when using the image and comply with all other terms or restrictions that may be applicable to that material.

In some cases, exceptions to copyright that permit limited use of protected works without the permission of the copyright owner may have be applied. We are confident that we have carried out due diligence in our use of copyrighted material as required, but we apologise for any inadvertent infringement of rights.

Digital copies of resources are made accessible for research for one of the following reasons:

- they are in the public domain;

- the rights are owned by the Publishers;

- we make them accessible under an exception or limitation to UK copyright law, as outlined in the Copyright, Designs and Patents Act 1988 (as amended);

- we have permission to make them accessible;

- or, there are no known restrictions on use.

If you believe that we have made a mistake and wish for your material to be removed from our site, please contact us at copyright@paul-mellon-centre.ac.uk.

Please include the following information with your request:

- Name and contact information, including email address and phone number.

- Identification of the resource for consideration of removal. Providing URLs in your communication will help us locate content quickly.

- The reason for the request.

The Publishers respond promptly, normally within 21 business days. We may remove the resource from our site while we assess the validity of the request. Upon completion of the assessment, we will take appropriate action and communicate that action to you. 